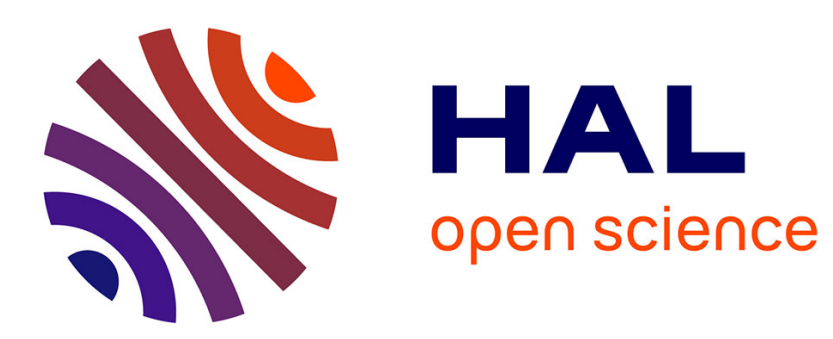

\title{
Innovations in Barge Transport for Supplying French Urban Dense Areas: A Transaction Costs Approach
}

Emeric Lendjel, Marianne Fischman

\section{To cite this version:}

Emeric Lendjel, Marianne Fischman. Innovations in Barge Transport for Supplying French Urban Dense Areas: A Transaction Costs Approach. Supply Chain Forum: An International Journal, 2015. halshs-01302684

\section{HAL Id: halshs-01302684 \\ https://shs.hal.science/halshs-01302684}

Submitted on 15 Apr 2016

HAL is a multi-disciplinary open access archive for the deposit and dissemination of scientific research documents, whether they are published or not. The documents may come from teaching and research institutions in France or abroad, or from public or private research centers.
L'archive ouverte pluridisciplinaire HAL, est destinée au dépôt et à la diffusion de documents scientifiques de niveau recherche, publiés ou non, émanant des établissements d'enseignement et de recherche français ou étrangers, des laboratoires publics ou privés. 


\title{
Innovations in Barge Transport for Supplying French Urban Dense Areas: A Transaction Costs Approach
}

\author{
EmericLENDJEL \\ Centre d'Economie de la Sorbonne, UMR 8174 du CNRS, Université Paris 1 Panthéon- \\ Sorbonne, France \\ lendjel@univ-paris1.fr
}

\section{Marianne FISCHMAN}

Centre d'Economie de la Sorbonne, UMR 8174 du CNRS, Université Paris 1 Panthéon-Sorbonne, Paris, France

mfischman@free.fr

\section{ACKNOWLEDGMENTS}

This article has been supported by the AgenceNationale pour la Recherchefor the research project Ville Durable / Fluide (ANR-09-VILL-0006-02). The authors thank the anonymous SCF referees and reviewer for their comments and suggestions that helped us improve our article considerably.

\begin{abstract}
Experimentations and innovations that involve barge transport flourish in France as the main leg for urban distribution of goods. Based on astudy of existing container barge transport (CBT) chains, this articleidentifies several obstacles impeding their use for urban river logistics: the complexity of these chains, on the one hand, and the level of specificity of assets involved in the loading and unloading phases, on the other hand. With the help of transaction costs economics, the articleshows that several innovations involving barge transport to supply French cities share a common aim to diminish transaction costs, especially in those phases. Thisarticlealso shows that coordination and pooling issues lead to adopt integrated or quasi-integrated governance structures to organize regular inland shipping lines necessary to supply dense French urban areas.
\end{abstract}

\section{KEYWORDS}

urbanriver logistics, innovation,coordination,governance structure, transaction costs economics

Nowadays urban freight transport is becoming a more and more complex matter. Mainly achieved through road haulage, urban freight transport suffers from increasing traffic jams that raise significantly its private and social costs (Henscher\&Pucket, 2005). Public authorities and private 
companies are looking for alternate solutions (Debah, 2010). In France, stakeholders are turning to inland river transport becausethis underused mode of transport can easily reach the heart of French main cities with less $\mathrm{CO}_{2}$ emissions (Raynard, 2012; TL\&Associés, 2006). River transport is indeed a mass-scale mode of transport thatachieves economies of scale and reduces negative externalities. Many experimentations and innovations involvingriver transport - mainly container barge transport (CBT) - are spreading for supplying urban dense areas (EICB/BVB, 2009; Gort, 2009;Kreutzberger, 2003; Nemoto et al., 2006; Van Hassel \&Vanelslander, 2011; Wiegmans, 2005; Wiegmans\&Konings, 2007), such as those done in France for shippers Auchan, Point $P$, or Franprix. The asset of penetrating the heart of major French cities on noncongested roads is undeniable on paper. It remains to be seen how this asset can effectively meet the expectations of all stakeholders and, in particular, how to combine the advantages of a mass-scale mode of transport with the growing importance of lean management and just-in-time in supply chain management (Guilbault, 2008). Many obstacles remain impeding the development of this kind of solution in urban areas. Urban density, particularly in Paris and the lle-de-France, and high land value impose strong constraints on spaces dedicated to logistics (Dablanc, 2011). Additionally, transaction costs are supported by agents willing to use river transport (Brooks et al., 2012). Indeed, the complexity of barging logistics raises coordination issues and transaction costs (Fischman \&Lendjel, 2012) that affect the decision-making process of both shippers and carriers.

In continuation of previous works (De Langenet al., 2006; Fischman \& Lendjel, 2011;Franc \& Van der Horst, 2010;Panayides, 2002; Van der Horst \&De Langen, 2008), a neo-institutional approach (Williamson, 1996) of river transport was chosen to understand how these issues are dealt with. Transaction cost economics (TCE) is a powerful theoretical apparatus to tackle coordination problems andexplain actual governance structures (market, hybrid, hierarchy) and strategies of firms to control transaction chains. Few studies(Beyer \&Debrie, 2013; Frémont, 2012; Paffoni, 2013; Raimbault, 2014)address theconditions of development of urban river logistics in France, despite the growing concern of environmental and congestion costs. Moreover, the neo-institutional approach is barely used in the literature to tackle urban logistics or urban freight transport. The most recent research on the topic (Gonzalez-Feliuet al., 2014; Macharis\&Melo, 2011) doesn't quote TCE when dealing with different kinds of governance structure used for logistics pooling (Moranaet al., 2014). Space is lacking here to develop a survey of the existing literature on urban logistics, but, significantly, the last one performed by Ducret and Rosset (2014) found no TCE approach inthis new field. Several significant exceptions are yet to be mentioned here (e.g.,Fabbe-Costes\&Roussat, 2011; Roy et al., 2006).

Following Yvrande-Billon and Ménard (2005), this article aims toshow that lowering the level of specificity of the involved assets in river transport is a condition for successful innovation in urban logistics.Butbecause of the well-known difficulty incollecting empirical data to assess the amount of transaction costs and the transaction's attributes (Ruester, 2010), ${ }^{1}$ this article is based only on interviews and case studies. Additionally, the articlestresses that coordination issues raised by urban

\footnotetext{
${ }^{1}$ Such attempts have nonetheless been done in Fischman and Lendjel (2012), where ex ante costs have been estimated at roughly $8 \%$ of the total costs of a bargeman operating a barge type Freycinet of 350 tons. If ex post costs are added (mainly of demurrages), the total amount of transaction costs exceeds $10 \%$ of total costs.
} But this evaluation is not relevant here in CBT. 
river logistics can be supported only by integrated or quasi-integrated governance structures, as observed for freight forwarders (Saeed, 2013). Thus, section 1 starts with the characteristics of the transaction of CBT, which is the existing way to supply goods through river transport. Indeed, goodsusually can't be deliveredin bulk in urban areas (except for building materials). They must be packed for transport, whatever the way (cardboard, pallet, palletized in a container). The CBT is thus the way to carry goods by river boats and is as such the logical starting point of this study. Section 2deals with observed governance structures of CBT chains in France. According to Williamson'sremediableness criterion, the observed governance structure of a given transaction is presumed efficient and aligned to its attributes. We point out thatthe monitoring and controlcosts explain the featuresof the observed structureson the Seine and Rhone rivers. Taking into account the existing attributes of the sub-transactions composing the CBT chains and their governance structures, the last section (Section 3 ) assesses recent innovations in urban river logistics and discusses their organizational and transactional conditions of success.

\section{Definition and Perimeter of the CBT Transaction Chain}

A presentation of transaction costs economics in logistics can be found in Roy et al. (2006) and, of course, in Williamson (1996). Briefly, this theory considers that all transactions bearex ante transaction costs (searching and negotiating costs, contracting costs) and ex posttransaction costs (monitoring costs, adaptation costs, claims, etc.). Firms are framing their transactions in definite governance structures ("market," i.e., outsourcing; "hierarchy," i.e.,internalization; "hybrid," i.e.,longterm contracts) that are supposedly minimizing transaction costs (according to the "remediablenesscriterion"; Williamson, 1996,2010). These costs are determined by the transaction's attributes (specificity, frequency, uncertainty).

According to Williamson, a transaction is a transfer of goods or services that "take[s] place at the interface between (rather than within) technologically separable stages" (Williamson, 2010, p. 685). Here, the transaction at stake focuses on CBT, which is the transfer of a service of containerized transport by barge, so that a container can be moved from one point (a port, for instance) to another (e.g., a warehouse in urban area) during a given time. ${ }^{2}$ The CBT transactional chain includes at least six sub-transactions (STs).

- ST 1 is the transfer of organization and coordination of a container transport by the shipper to an economic unit (usually different from the shipper, corresponding to the missions of a freight forwarder, but can be performed by a shipping company).

- ST 2 is the transfer of the rights to use a transport capacity between the transport organizer and the owner of barges (or of slots) or of containers.

- ST 3 is the transfer of the CBT service going from quay to quay from the transport organizer to the CBT economic unit. This ST is itself likely to be split in two: the CBT itself and the barge propulsion by a pusher tug and a crew.

- ST 4 is the transfer of thecargo-loading service on barges between the transport organizer (often the shipping company) and the handling company at the departure quay.

- ST 5 is the transfer of the cargo-unloading service from barges between the transport organizer (often the shipping company) and the arrival quay handling company.

- ST 6 is the transfer of pre- and end-road haulage services between the transport organizer and road haulage operators.

\footnotetext{
${ }^{2} \mathrm{~A}$ container isastandardizedintermodal unit load device (usually20 or 40 feet long) designed to facilitate transfers of cargo between different modes of transport in the safest way.
} 
The provisionof a containeris anST prior to the transaction of CBT. The containerrevolutionizedtheway we think abouttransportationbecause, somehow, goods are not moved anymore, but rather their container is, whether empty or full. Yet, even though it is essential, this ST remains peripheral becausethe container is a loading unit of maritime origin. CBT, therefore, can be considered to bea ST of the container transport's transaction.If the masterlink in thetransaction chain ismaritime,inland waterway transportthenappears as aterrestrialextension of amaritimetransport. ${ }^{3} T$ Then, the freight forwarder or the shipping company usually hasthe commercial function to fill the containers, to position them at the customer's warehouse,or evento organize their stuffing-strippingin the case of grouping.

Each of these STs includes many sub-STs or second-rank STs. ST4 or ST5 (loading-unloading containers, managing containers at quaysides) are in themselves complex sets of sub-STs, even more so now that the container revolution has taken place. Indeed, the terminal operator must be able to implement the vessel-loading plan sent by the shipping line operator. Thus, the formerhas to face several external constraints to comply with container-handling procedures with a precise order of loading-unloading containers and, therefore, with onshore container pre-arrangements (see Zhao \&Goodchild, 2010). Operatorsalso face their own constraints (minimal number of container movements, optimization of available space, management of human and material resources, etc.) to comply with loading plans (Galbrun\&Le Du, 2007). Though interdependent, the container loadingunloading sub-ST is sometimes dissociated from the quay container handling sub-ST. As for the container inland navigation operation itself (ST3), it is likely split into the CBT operation and the barge propulsion by a pusher tug, the latter being sometimes divided in two parts: the availability of a crew and the provisions of a pusher tug. Other sub-STs may occur when local pushers (or harborpusher tugs) move barges in a port, whereas power pusher tugs make convoys of lashed barges for long hauls between ports. Thus, although it appears to be simple, the CBT transaction is actually quite complex.

According to awell-known mechanism, expanding demand by container standardization leads to the segmentation of the barge transport transaction into an increasing number of STs. Nevertheless, the actual number of governance structures framing these STs is surprisingly reduced compared to what is theoretically possible.

\section{Governance Structures of French CBT Chains}

A specific extraction from the $\mathrm{ECHO}^{4}$ national survey database (realized by the INRETS in 2004) shows that $100 \%$ of the 23 CBT shipments found in the survey (from a total of 10,462 shipments involved in the survey) are outsourced and involved at least three operators. In other transport chains, only $7 \%$

\footnotetext{
${ }^{3}$ Note that it could be part of the transaction's perimeter when CBT becomes independent of the maritime chain as it is on the Rhine (Zurbach, 2005).

${ }^{4}$ ECHO (Envois - CHargeurs- Opérateurs de transport) is a national survey designed to understand shippers' practices and whose measurement unit is the shipment sent by a shipper (Guilbault, 2008).
} 
of the shipments - parcels excluded - require at least three operators (Guilbault, 2008, p. 108; Bréhier et al., 2009, p. 8). Hence, the CBT is usually more complex to organize than the other (often smaller) transport chains. How can weexplain thiscomplexity? Could it impede the development of urban river logistics? TCE is the appropriate tool to deal with these questions.

As Williamson stated, "the critical dimensions for describing alternative modes of governance (...) are incentive intensity (...), administrative command and control (...), and contract law regime (...)"(Williamson, 2010, p. 681). Following this typology, structures governing STs in French CBTs have to be assessed.

The first point to consider is the theoretical number of combinations of governance structures permitted by the transactional chain of the river transport of containers. Considering that each of the six STs (if the river interconnection service is excludedas public service) may be achieved by at least three governance structures (spot market, hybrid or long-term contract, hierarchy), the decision tree includes a set of 729 possible combinations $\left(3^{6}=729\right)$ of governance structures for this transactional chain (Williamson, 2010). The longer the chain, the bigger the set of possible combinations. ${ }^{5}$ This exponential character of the economic complexity of the chain contrasts sharply with the very limited number of combinations (six) observed in the river transport of containers in France. If an inventory of these chains has already been done (Frémont et al., 2009; IAU, 2008; VNF, 2009; Zurbach, 2005), their typology and their understanding usingthe insights of transactional analysis still has to be done for the French basins.

Among the six regular services observed on the Seine River between Le Havre and Paris (Marfret/Fluviofeeder, Logiseine-Logiyonne, Maersk, MSC, RSC/Greenmodal, SNTC Carline) and the two (Logirhône, RSC/Greenmodal) existing in the Rhône-Saône river basin, four services are really provided by barge operators, Maersk and MSC contracting with Logiseine to chart Logiseine's barges (VNF, 2009). ${ }^{6}$ The governance structures of CBT operators on the Seine and the Rhône are all integrated or quasi-integrated, without any arm's length transactions, as shown in Table 1 . Among the 48 STs of these eightservices, $63 \%$ have a hybrid governance structure and $21 \%$ are fully integrated (hierarchy). Even when a barge operator has no specific agreement with a handling operator, thecontract is usually settled on an annual basis even if it is proportional to the volume of containers handled. Hybrid modalities predominate when complete integration of the considered ST is not possible (lack of funds) or not wanted (for incentive reasons). Following Williamson (1996), the governance structure of a transaction is presumed aligned on its attributes, namely, asset specificity (i.e., level of loss associated to alternate use of assets involved in the transaction or

${ }^{5}$ Let $n$ be the number of elements in the subset of governance structures and $p$ the number of transactions at stake; $n^{p}$ is the total number of available combinations. Thus, if all the governance structures are taken into account (franchise, joint-venture, quasi-integration, long-term agreements, etc.), the number of possibilities increases more quickly.

${ }^{6}$ Other CBT operators may operate but not on a regular basis. They are chartered by a regular operator and operate as sub-contractors. 
redeployability'slevel of the asset), frequency (number of times a transaction occurs in a given period), and uncertainty (related to the environment of the transaction and to the behavior of parties in condition of bilateral dependency). In terms of CBTs STs, asset specificity, and frequency are mostly determinant.

Table 1: Governance Structures (M-Market, X-Hybrid, H-Hierarchy) of CBT

\begin{tabular}{|c|c|c|c|c|c|c|c|}
\hline $\begin{array}{l}\text { Sub- } \\
\text { Transacti } \\
\text { ons }\end{array}$ & $\begin{array}{l}\text { Synthes } \\
\text { is }\end{array}$ & ST1 & ST2 & ST3 & ST4 & ST5 & ST6 \\
\hline Label & $\begin{array}{l}\text { Synthesis } \\
\text { of GS for } \\
\text { the } \\
\text { transaction } \\
\text { chain }\end{array}$ & $\begin{array}{l}\text { Transfer of the } \\
\text { container } \\
\text { transport } \\
\text { organization } \\
\text { between a } \\
\text { shipper and a } \\
\text { forwarder }\end{array}$ & $\begin{array}{l}\text { Transfer } \\
\text { of rights } \\
\text { to use a } \\
\text { transport } \\
\text { capacity } \\
\text { between } \\
\text { the } \\
\text { transport } \\
\text { organizer } \\
\text { and the } \\
\text { owner of } \\
\text { the } \\
\text { capacity }\end{array}$ & $\begin{array}{l}\text { Transfer of } \\
\text { the quay- } \\
\text { to-quay } \\
\text { transport } \\
\text { operation } \\
\text { between } \\
\text { the } \\
\text { transport } \\
\text { organizer } \\
\text { and the } \\
\text { barge } \\
\text { operator }\end{array}$ & $\begin{array}{l}\text { Transfer of } \\
\text { the } \\
\text { maritime } \\
\text { port } \\
\text { handling } \\
\text { from the } \\
\text { transport } \\
\text { organizer } \\
\text { to the } \\
\text { handling } \\
\text { company } \\
\text { at the } \\
\text { departure } \\
\text { quay }\end{array}$ & $\begin{array}{l}\text { Transfer of } \\
\text { inland port } \\
\text { handling from } \\
\text { the transport } \\
\text { organizer to } \\
\text { the handling } \\
\text { company at } \\
\text { the arrival } \\
\text { quay }\end{array}$ & $\begin{array}{l}\text { Transfer of the pre- and } \\
\text { end-road haulage } \\
\text { between the transport } \\
\text { organizer and the road } \\
\text { haulage operator }\end{array}$ \\
\hline \multicolumn{8}{|l|}{ SEINE BASIN } \\
\hline $\begin{array}{l}\text { Fluviofe } \\
\text { eder }\end{array}$ & XHHMMX & $\begin{array}{l}\mathrm{X} \quad \text { (Marfret's } \\
\text { subsidiary; long- } \\
\text { term contract } \\
\text { with MSC) or M }\end{array}$ & $\mathrm{H}$ & $\mathrm{H}$ & $M$ & $M$ & $\bar{x}$ \\
\hline $\begin{array}{l}\text { Logisein } \\
\text { e/Logiyo } \\
\text { nne }\end{array}$ & MHXXXX & $M$ & $\begin{array}{l}\mathrm{H} \text { (Barges } \\
\text { of } \\
\text { Logiseine) }\end{array}$ & $\begin{array}{l} \\
\text { (Logiseine } \\
\text { is a joint } \\
\text { venture } \\
\text { held by } \\
\text { CFT and } \\
\text { TN) }\end{array}$ & $\begin{array}{l}X \\
\text { (Logiseine } \\
\text { is a joint } \\
\text { venture } \\
\text { held by } \\
\text { CFT and } \\
\text { TN) }\end{array}$ & $\begin{array}{l}\mathrm{X} \text { (CFT and TN } \\
\text { shareholders of } \\
\text { PTSA) }\end{array}$ & $x$ \\
\hline Maersk & XXXXXX & $\begin{array}{l}X \quad \text { (Long-term } \\
\text { agreement with } \\
\text { CFT) }\end{array}$ & $\begin{array}{l}\mathrm{X} \text { (charter } \\
\text { capacity } \\
\text { to CFT) }\end{array}$ & $\begin{array}{l}\mathrm{X} \\
\text { (Logiseine } \\
\text { is partially } \\
\text { held by } \\
\text { CFT) }\end{array}$ & $\begin{array}{l}X \\
\text { (Logiseine } \\
\text { is a joint } \\
\text { venture } \\
\text { held by } \\
\text { CFT and } \\
\text { TN) }\end{array}$ & $\begin{array}{l}\mathrm{X} \text { (CFT and TN } \\
\text { shareholders of } \\
\text { PTSA) }\end{array}$ & $\bar{x}$ \\
\hline MSC & XXXXXX & $\begin{array}{l}\text { X (Long-term } \\
\text { agreement with } \\
\text { CFT) }\end{array}$ & $\begin{array}{l}\mathrm{X} \\
\text { (Charter } \\
\text { capacity } \\
\text { to CFT) }\end{array}$ & $\begin{array}{l}\text { X } \\
\text { (Logiseine } \\
\text { partially } \\
\text { held by } \\
\text { CFT) }\end{array}$ & $\begin{array}{l}\mathrm{X} \text { (TN MSC } \\
\text { is a joint } \\
\text { venture } \\
\text { with TN) }\end{array}$ & $\begin{array}{l}\text { (CFT and TN } \\
\text { shareholders of } \\
\text { PTSA) }\end{array}$ & $x$ \\
\hline $\begin{array}{l}\text { RSC/Gre } \\
\text { enmodal }\end{array}$ & XHHXMX & $\begin{array}{l}\mathrm{X} \text { (CMA-CGM's } \\
\text { subsidiary) or M }\end{array}$ & $\mathrm{H}$ & $\mathrm{H}$ & $\begin{array}{l}\mathrm{X} \text { (GMP is a } \\
\text { joint } \\
\text { venture } \\
\text { held by } \\
\text { CMA-CGM } \\
\text { and DPW) }\end{array}$ & $M$ & $\begin{array}{l}\mathrm{X} \text { (LTI is part of } \\
\text { Greenmodal) }\end{array}$ \\
\hline $\begin{array}{l}\text { SNTC- } \\
\text { Carline }\end{array}$ & XXXMHX & $\begin{array}{l}\text { X (Alliance with } \\
\text { Soufflet) or M }\end{array}$ & $\begin{array}{l}\mathrm{X} \\
\text { (Alliance } \\
\text { with } \\
\text { SCAT) }\end{array}$ & $\begin{array}{l}\text { X (Alliance } \\
\text { with SCAT) }\end{array}$ & $M$ & $\begin{array}{lr}\text { H (SNTC } & \text { owns } \\
\text { handling of } \\
\text { Nogent/Marne) }\end{array}$ & X (Alliance with STTI) \\
\hline
\end{tabular}




\begin{tabular}{|l|l|l|l|l|l|l|l|l|}
\hline \multicolumn{2}{|l|}{ RHONE-SAONE BASIN } \\
\hline $\begin{array}{l}\text { Logirhôn } \\
\text { e }\end{array}$ & MHHMXX & M & $\begin{array}{l}\text { H (CFT's } \\
\text { Barges) }\end{array}$ & $\begin{array}{l}\text { H (CFT's } \\
\text { subsidiary) }\end{array}$ & M & $\begin{array}{l}\text { X (CFT is a } \\
\text { shareholder of } \\
\text { Lyon Terminal) }\end{array}$ & X \\
\hline $\begin{array}{l}\text { RSC/Gre } \\
\text { enmodal }\end{array}$ & XHHXMX & $\begin{array}{l}\text { X (CMA-CGM's } \\
\text { subsidiary) or M }\end{array}$ & $H$ & $H$ & $\begin{array}{l}\text { X (Eurofos } \\
\text { is a joint } \\
\text { venture } \\
\text { held by } \\
\text { CMA-CGM } \\
\text { and DPW) }\end{array}$ & $\begin{array}{l}\text { X (LTI is part of } \\
\text { Greenmodal) }\end{array}$ \\
\hline
\end{tabular}

In ST1, CFT subsidiaries (Logiseine/Logiyonne/Logirhône)are the only ones to perform the organization of the CBT with a market governance structure. The others intervene mostly in broader maritime chains within hybrid governance structures.Mostly, this ST is part of door-to-door services supplied by container shipping lines and, as such, needs to be controlled through hybrid - at least governance structures by their parent companies. The specificity of this kind of transport chain requires an expertise (human-asset specificity)in freight forwarding and dedicated organizational routines between the shipping line and the CBT line. But the main asset is the brand, the reputation asset necessary to drain customers in this highly competitive market. With behavioral uncertainty, this specificity explains the governance structures framing the ST1.

The transfer of rights to use a capacity (ST2) is supported logically by hybrid ( 5 over 8 ) and hierarchic (3 over 8) governance structures because of the regularity and frequency of the ST at stake (Notteboom, 2006). But sometimes, during peak seasons, additional capacity can be chartered through short-term contracts. Assets in large-gauge basins have an average payload of 200 containers (TEU) on the Seine (EICB/BVB, 2009, p. 51). Because of the lack of large-gauge interconnections between the main French inland waterway basins (Rhine, Rhône, Seine), barges on them have a high specificity. Their transfer to different basins requires a maritime move with a tugboat, implying high redeployment costs. From this point of view, barges and pushers have a lower specificity becausethey can be separated and connected quite as easily even if they work together and can be used for other transports than containers.

In ST3,long-term contracts (50\%) and hierarchies (50\%) are the appropriate governance structures to provide a regular service because of the frequency and the regularity of the ST at stake. Niérat(2014)shows that aself-propelledrivercontainer shiponthe Rhônebasinmakes about66tripsa year, with a rate ofloaded trip of $99 \%$ anda fill rate expressedin TEUsof $72 \%$. With four shuttles per week between Le Havre and Gennevilliers (IAU, 2008; VNF, 2009), Logiseine cannot rely on spot transactions to purchase every week the human and physical assets (with more or less high degrees of specificity) needed, except during peak activity to increase its capacity. It is the same for all the other operators because of the networked nature of this activity.Barge operators, whether employee or not, accumulate knowledge - often informal - and skills about theirboats, the river basin, and the practices of loading andunloading in different ports (Fischman \&Lendjel, 2011). If theydo not own the boat, theynonetheless accumulate experience and expertise on specific equipment (pushers and barges) theywill not find elsewhere in another French company. Integration or quasi-integration of specific human and physical assets is needed for this ST. But, in order to have a higherincentive device than hierarchy, the CFT sometimes uses a singular hybrid structure (SociétéEn Participation 
[SEP]) for some of its pushers. ${ }^{7}$ The SEP pools resources from each partner. CFT rents the physical asset (the pusher tug) and a small dedicated company (SARL) rents human resources (two crews of six people to secure a 24/24 driving each week). The SEP sells a pushing service per hour or kilometer (with a yearly contract) to CFT. Logiseinecommercializes the capacity of transport on its barges and asks CFT to make the transport service. Thus, CFT subcontracts the pushing service to the SEP. The SEP assumes earnings and operating expenses of the pusher tug so that each partner is directly involved in its operating income. Particularly, the structure incites the crew to take care of the equipment (a pusher tug is very expensive, which explains why CFT needs to be part of the SEP), its fuel consumption (main variable cost), and the service liability and punctuality. This hybrid governance structure (i.e.,quasi-integration) is often used in road haulage (Fernandez et al., 1998) but relatively uncommon in river transport, even within CFT. Bycontrast, other more usual hybrid structures (regular sub-contracting, long-term charter, barge transport pool, etc.) can be seen on the Rhine (Zurbach, 2005).

Regarding ST4, hybrid governance structures (5 over 8 ) dominate market governance structures (3 over 8 ) in maritime ports even though the latter are highly sitespecific for inland navigation agents (Franc \&Van der Horst, 2010). Inland quays mustbe located in the vicinity of maritime quays - where containers are stacked - in order to minimize space and time costs necessary to move containers from a ship to a barge.But using maritime quays is costly for barge transport operators (oversized equipment, random availability of the quay, etc.) (Fischer et al., 2003, p. 27) and advantageous for the terminal operators (higher rate of handling capacity use).Barge operators are faced with the trade-offs between extra costs of maritime handling (but at the vicinity of inland quays) and additional costs of a dedicated handling quay with the related transfer of containers from inland to the maritime quays.That's the reason why long-term contracts dominate here.This logic also prevails for the vicinity between warehouse and inland quays. The location of an inland quay in a logistics cluster area strengthens its site specificity becauseof the need to dedicate space for loading and unloading containers. Second-rank STs are here also logically integrated or quasi-integrated.

ST5 offers a diversity of governance structures (threemarkets, fourhybrids, onehierarchy). Most often, barge operators are shareholders of inland terminal operators. Carrying containers entails dedicated assets from barge and terminal operators to reach high levels of productivity. Terminal operators need to dedicate specific cranes and engines (docks, gantry cranes, stacking straddle carrier, stacking space, etc.) to perform container handling for barges. Barge operators need specific barges designed to carry containers and dedicated terminals to load and unload them. This mutual dependency generates risks of underinvestment and opportunism (Joskow, 1987; Klein, 1988). This concern is particularly high during the launching phase of a new service, as was the case on the Seine in 1994. A barge transport operator (Logiseine) and two terminal operators in Le Havre and in Gennevilliers (near Paris) had to generate simultaneously large investments to start a regular line. Contrary to maritime container terminals that couldeasily allocate part of their resources to container bargeswhen they dock (when free of the container ship to be loaded or unloaded) (Steenken et al., 2004), inland container terminals need dedicated assets. The large amount of required capital and its negative profitability in the short term explains why public port authorities are often involved during the launching phase of a CBT line. For instance, Paris Terminal SA, the inland public port operator, was a shareholder of Logiseine barge operator at its very beginning.

\footnotetext{
${ }^{7}$ Interview with S.Fortrye, CFT's Directorof Public Relation (November 11, 2010).
} 
Additionally, the location of quays in the vicinity of a dense urban area creates a strong site specificity for inland terminal operators in this ST. Based on Joskow (1987) and Klein (1988) we know that vertical integration is likely to occur when dedicated assets are involved in the transaction in order to avoid hold-up risks associated withthe quasi-rent at stake in dedicated investments. The exceptionally long duration of contracts (from 15 to 30 years depending on the terminal) of land concession (quasi-integration of site) is an indicator of the high level of site specificity and of the quasi-rent it generates (Monteverde\&Teece,1982).In STs of second rank of handling service (ST4 and ST5), the integration of human assets (dockers first, then crane drivers) has been done andthe market governance structure (via the dockers' intermittence system) prevailed before the reforms indocker status in 1992 and $2008 .{ }^{8}$ They aim to integrate dockers intostevedoring companies and thus to promote hierarchical coordination of their activities (Galbrun\&Le Du, 2007). The container revolution increased the specificity of stevedores' human capital. The stevedoring industry has changed because of the increasing technicality and capitalistic intensity necessary to handle containers. Hence, dock workers and crane drivers have acquired a more specific technical knowledge and a higher degree of specificity. Asset specificity prevails also for container-handling equipment (especially gantry cranes and, toa lesser extent, reach stackers). Hierarchy seems to be the best governance structure here given the actual attributes of this ST.

One hundred percent of ST6's governance structures are hybridsbecauselong-term contracts are necessary to convince road carriers to invest in skeleton trailers configured to carry containers. Bruno Kauffmann'stressed that the "difficultyinstarting the activitywas that road carriers would notbuyskeletontrailers;sowe had to findowner-operators whowere willing toinvest, hence our commitment to theseowner-operators." Relationships withthese carriersarestructured by framework contracts, generally on an annual basis (Eccles, 1981), butaccompanied byspotcontracts with"bigdoers"in case ofpeak activity.

It is thus clear that, among the three dimensions described by Williamson (incentive intensity, administrative command and control, contract law regime), control strongly dominates the CBT chain. If the number of services can be explained by the amount of investments necessary to get network economies at the current level of demand, the small number of types of chainof governance structure observed here can be explained by the attributes of the STs composing that transaction chain. High frequency and regularity of transactions and the quite high degree of asset specificity may also explain whyonly four barge operators can be found in CBT on the Seine and Rhône rivers.

Hence, as shown, the CBT transaction chain governance structure is integrated or quasi-integrated, which demonstrates that transaction costs are sufficiently high to prevent market governance structure, in compliance with Williamson's remediableness criterion.The domination of hybrid governance structures (68\%) confirms the complexity of CBT chains identified in the ECHO survey.Such a complexity generates highex antetransaction costs for shippers willing to use CBT for

${ }^{8}$ Law no. 92-496 of June 9, 1992, changed the working arrangements in maritime ports and law no. 2008-660 of July 4,2008 , related to port reform.

${ }^{9}$ Interview of Bruno Kauffmann, CFT's commercial director (June 6, 2012). 
theirurban supply chain. Freight forwarders handle precisely this complexity and help to lower ex ante transaction costs, but up to a limited extent. In particular, ST5, with its high level of site specificity, and ST6, with the difficulty of convincingroad operators to invest in dedicated assets, seem to impede the use of urban river logistics.

\section{Discussion: Which Governance Structuresare suitable for Urban River Logistics?}

Lowering the level of asset specificity can be considered here to bea way to lower CBT transaction and production costs. Given thegovernance structurescurrentlygoverning CBT transactions and theirSTs, and given their attributes, which trends could we then expect for the development of urban river logistics? Recent innovations are first assessed here in that respect before tackling the new concept of Distri-Seine put forward by CFT.

\section{Production and Transaction Costs in Recent Innovations in Urban River Logistics}

Two experiments to supply supermarkets are regularly citedas examplesof sustainableurban logistics inthe Paris area: Monoprix's supply (achieved by its subsidiary Samada) that accessesby rail the HalleGabrielLaméofParisBercy,on the one hand (Delaître\&De Barbeyrac, 2012), and more recently, on theother hand, Franprix(Casino Group subsidiary),whichrelies ontheriverport ofla Bourdonnais in Paris (Greenport, 2013). This last experiment started in September2012 aftertwoyears of study andone yearcommercialengineering.Operated in partnershipwithNorbertDentressangle (for road haulage) andSCAT (the barge operator), the servicecarries each day 26 containersby barge from the river portofBonneuil-sur-Marne (94) to the quayof La Bourdonnaisin the 7th arrondissementofParis. Then, the containers are deliveredby truckto 80 westbound storeswithin a radiusof $4 \mathrm{~km}$. The delivery of parcels by Vert-Chez-Vous, a courier using green modes of transport on the model of DHL in Amsterdam, is another example. Pickups and parcel deliveries in Paris are achieved with several electric tricycles thatmeet a barge at different points of loading and unloading docks along the Seine banks of Paris on a given schedule.

Those last innovations in urban river transport help to identify the possible economic and organizational conditions of barging logistics in urban areas. Regarding production costs, several criteria can be stressed:

1. Barging is a mass-scale mode, and the volume of demand must reach the break-even point on a regular basis, taking into account that it depends on many parameters (Beelen, 2011). For Franprix this minimal volume appears to be 26 containers per day, with a loading rate of $54 \%$ (total capacity is 48 containers). The threshold effect based on fixed costs and transshipment costs is high in river transport and could be met either with a big doer - such as Franprix - or by pooling several deliveries by different shippers,such as for Vert-chezvous.Pooling helps to diminish average costs but necessarily generates transaction costs. If ex ante transaction costs are necessarily high when dealing with a big doer, they need to be considerably lower if pooling is expected.

2. Last kilometers have to be performed by road. Thus, barge and truck rotations have to be synchronized. A sufficient number of trucks are scheduled to make deliveries of containers from the barge, which serves as a floating warehouse.Important organizational routines are thus necessary for a smooth urban river logistics and, thus, integrated or quasi-integrated governance structures.

3. Road transportis the most expensive, so kilometers traveled by road should be minimized to maximize those of the waterway, following Palander'slaw of refraction (Aydalot, 1985, p. 24). Docking cost apart, this logic leads to multiplyingthe number of calls of the barge to minimize ton-kilometers performed by trucks (or by bikes, as designed by Vert-Chez-Vous). But the importance of fixed costs in handling and the scarcity of river docks connected to the road are not compatible with the multiplication of these river access points. A solution developed 
by SteunpuntGoederenstromen (Gort, 2009) is to internalize the ST of handling (ST4 and ST5) by a side-loader gantry crane installed on the barge, which loads and unloads containers sideways. This solution has the advantage of reducing river ports' high degree of sitespecificityfor logisticians.

4. The scarcity of available space on urban riverbanks involves a zero storage time of containers (or only reduced time loading and unloading). The storage can then be done on a barge or in a warehouse on a suburb river dock where land constraint is lower. When flows are regular but have unpredictable content and temporal specificity, as in the case of Franprix, a warehouse on the outskirts of the town reduces the access time to the city center. In that case, Ports of Paris (at Gennevilliers)and Edouard Herriot (at Lyon) are well positioned, also because of their connections to maritime ports. When flows are regular with predictable content, the location of the warehouse in a seaport connected to the river system reduces the number of transshipments (see Radicatel, for example, which offers a logistics area dedicated to the river close to the port of Le Havre).

5. Finally, the total cost of the entire river logistics chain must be less than the cost of alternative schemes. If Franprix's supply chain costs by barge proves higher than that of a road scheme, as notesStéphaneBonneton(driver of this innovation at Norbert Dentressangle), ${ }^{10}$ it is not the case if we include marginal social costs. According to the calculations put forward by the company, this solution would remove 374 trucks from Parisian roads. The forthcoming probable introduction of congestion-charging systems in major French cities should logically make a river-road scheme less expensive than any road scheme.

On a transactional level, the examples clearly revealat least three obstacles impeding river supply of cities:

1. Engineering costs of the scheme, which can be subsumed under the category of ex ante transaction costs, are important. Urban logistics by barge indeed require a tight coordination of the actors, hence,long contracts with one (or several) barge operators, one (or several) road operators, one (or several) port operators, one (or several) terminal operators, and one (or several) storage operators. Costs of organization and coordination are logically high enough, especially with the frequency of STs involving assetand sitespecificity, to justify the quasi-integration of the chain. In the case of Franprix, it took three years to initiate such a scheme (incidentally made feasible by subventions and significant investments supported by the port authority). Its importance is relative, however, with regard to the innovative character of the transaction. Indeed, any innovation can't but generate many ex ante transaction costs. And, similar to any other cost, the unit transaction cost falls as the transaction volume increases. Spreading this innovation should drop significantly ex antetransaction costsof urban river logistics in the future. As StéphaneBonnetonstressed it, "many cities have contacted us for a similar service." Incidentally, this project has increased thebrand-name capital of the company. But except for some shippers in the retail sector,only few shippers have sufficient volumes to adopt such river logistics. The threshold necessary to get economies of scale in barge transport is achieved only by pooling flows among several

\footnotetext{
${ }^{10}$ In spite of its expensive character, this solution unveils a strategic choice behind this "green logistics." The scarcity of space and the site specificity of Parisian quays led Franprix to be the first to occupy this free space in a growing congested context.
} 
customers.Additionally, as barge logistics includes pre- or end haulages by road, the organizer must provide door-to-door transportation solutions to lower shipper's transaction costs. Yet,ex ante transaction costs are still high in river logistics. For example, the delay proposed by RSC to position a container in the warehouse of a client is almost twice longer for a barge-truck transport (four days) than for an all-truck transport (two days), with the same transit times (two days for Paris-Le Havre). This delay increases the ex ante transaction costs of a barge-truck trip compared to an all-truck trip for a shipper (Lendjel, 2013). Unfamiliar with barge logistics and its transaction costs, the shipper turns more readily to road haulage, which has the advantage of ease and flexibility, despite its high cost.The development of urban logistics by barge therefore requires a significant reduction in its transaction costs.

2. Second, the barge-truck system implemented by Norbert Dentressangle for Franprixreveals the sitespecificity of river ports in major cities. Indeed, the scarcity of available space on the docks, combined with increasing traffic jams (and thus the prospect of the inexorable rise of environmental taxation), justifyFranprix's strategic choice to take in advance a strategic position in the heart of Paris through long-term contracts with Port de Paris and Paris Terminal. The increase of river logistics can't but raise urban docks' degree of sitespecificity. Several ways are possible to reduce this specificity. One of them comes from the fact that, in urban areas, the relevant unit of loading is often the pallet or the mini-container rather than the container. At that level,one must look for economies of scale necessary for urban river logistics. This observation has led the Dutch to innovate - unsuccessfully - with Distrivaart, a barge that carries palletized goods between distribution centers and supermarkets (Wiegmans, 2005). In terms oftransactional analysis, Distrivaart internalized theservices usually providedin the warehouse, namely,managementof pallets andloading and unloadingof vehicles. Italso had theadvantage of eliminatingstevedoring usually made by a terminal operator and thento reduce thedegree of site specificityof riverdocks.Developingurbanriverlogisticsinvolves rethinkingthe scopeand attributes ofSTs included in thistransaction.

3. Third, the scarcity of space in urban dense areas is not conducive to traditional logistics. Because of its dimensions, a container cannotbe stored easily in a street on a parking place. In addition, loading and unloading a container at the delivery point is a more complex task in urban dense areasthan in logistics areas, because a container needs either a quay or to be on the floor to be discharged from usual skeleton trailers at shippers' destination. A special liftgate could be added to the rear of the truck, as Norbert Dentressangle did it for its container trucks dedicated to Franprix, and, as such, could increase the cost of the solution. Finally, loading and unloading a truck is a space- and time-consuming process that has to be optimized, particularly inside the city because of the externalities it generates.

\section{The Distri-Seine/CFT Case}

In Norbert Dentressangle'ssolution, reachstackers are used to load and unload containers into and from a boat calling at the quay of La Bourdonnais. Handling equipment of ST5 isless specific now, with a lower degree of physical asset specificity and a quay with a lower degree of site specificity. By decreasing the level of asset specificity, organizational innovations help to lower transaction costs. An interesting aspect here was the fact that the initiative was madeby a shipper, akin to improvingits reputation asset by greening its supply chain. The engineering process was achieved by a nonriver transport company, a company thatcomes from road transport and is familiar with the characteristics of shippers' needs while supplying cities. 
Another solution called "Distri-Seine"was launched in April 2014 by a river transport company, the CFT. Likewise, this solutionaims to decrease the level of asset specificity of ST4 and ST5 in order to lower transaction costs. As a matter of fact, ST4 and ST5 handling equipment is internalized on the barge in ST3 - and becomes ST3's second-level STs - by a RoRo process of loading and unloading vehicles with lateral built-in ramps. The boat is equipped with elevator systems combined with lateral drawbridges that allowthecharge and discharge of electric middle-size trucks from the boat side to the quay and conversely. In addition, the boat supplies electric power to the trucks during their trip.

Figure 1 :CFT's innovative concept of Distri-Seine

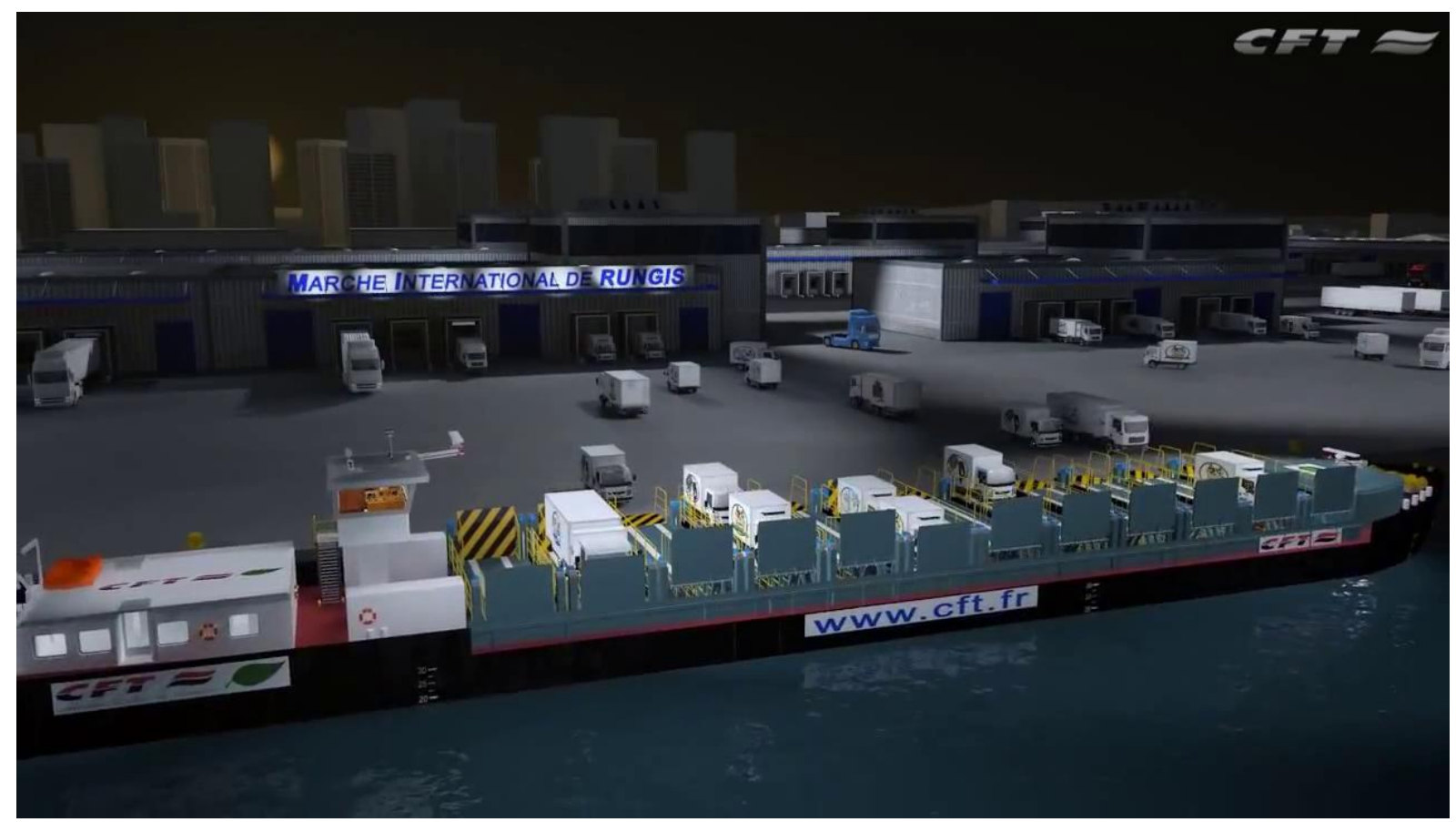

Source: CFT (http://www.cft.fr/5-1-1-26-pix-fr/cft-Actu Distri Seine.html)

The concept is not implemented yet, but, according to FerencSzilàgyi, ${ }^{11}$ trucks could be loadedon the boat early in the morning near the Rungis International Market, the main food market place of the region lle-de-France, or at the port of Gennevilliers, the main container terminal of the region. A couple of hours later, around 9am, thebarge would arrive ata Parisdock, wheredriverswould be expectedto recovertheir vehicle andmaketheir distributiontour.Meanwhile,theboat would move to another quay in Paris to unload other trucks and wait for the return of the empty trucks or restart to Rungisto retrieveanother batchof trucks. No idletime is lost on theboat for the truckdrivers because they are transported by bus to the quay.

Because of the high level of specificity of physical assets (barge, electric trucks) and the level of coordination of their flows, the governance is necessarily integrated or quasi-integrated. From the shipper's point of view, this solution lowers itsex antetransaction costs because this ready-to-use solution is a door-to-door service (lastmiles included) provided by one integrated company instead of many subcontractors. It also helps to lower ex posttransaction costs with an improved reliability of a congestion-free transport chain. From the carrier's point of view, this solution diminishes the level of asset specificity involved in ST4 and ST5. The level of site specificity of quays is considerably lowered

\footnotetext{
${ }^{11}$ Interview withFerencSzilàgyi, market leaderat the CFT (April 22, 2014).
} 
because no fixed handling equipment is needed anymore (with the exception of electrical outlets to provide power to the barge during its call), contrary to Norbert Dentressangle's solution. But, in losing load capacity and increasing the technical complexity of the system, it increases the level of asset specificity of barges in ST3. ST3's governance structure could switch toward hierarchy instead of the hybrid.

\section{Conclusion}

Startingwiththe analysis of the existing ways to supply French cities by barge, this article has identified several obstacles impeding the use of traditional CBT chains for urban river logistics. The analysis of CBT's STs unveils two main blocking points: the complexity of their chain on the one hand and the level of specificity of assets involved in ST4 and ST5 on the other. Several innovationsinvolving a barge transport to supply French cities have then been assessed. They share a common aim to diminish transaction costs especially in the ST4 and ST5. This is the case with DistriSeine, Distrivaart, Norbert Dentressangle/Franprix, SteunpuntGoederenstromen,andVert-chez-vous, in which various solutions to despecify the assets and sites involved in those STshave been tried by stakeholders. As we can see, innovations in urban river logistics can't be successful without lowering transaction costs. But, of course,production costs are also another major aspect of the equation, which have been already stressed elsewhere. The objective of this study was simply to draw attention totransaction costs in barge transport, if public authorities wish to encourage its development for urban logistics, and to discuss organizational and transactional conditions of innovations following this aim.

\section{References}

Aydalot, P. (1985).Economie régionale et urbaine. Paris: Economica.

Beelen, M. (2011).Structuring and modelling decision making in the inland navigation sector. PhD Dissertation. Antwerp: AntwerpUniversity.

Beyer, A., \&Debrie, J. (Eds.).(2013).Les métropoles fluviales: Concilier aménagement et logistique pour un développement urbain durable. Paris: L'œil d'or: Critiques \&cites.

Bréhier, O., Gavaud O., \&Guilbault, M. (2009).Les chaînes organisationnelles dans le transport: Enseignements de l'enquête ECHO. Nantes: Rapport du CETE de l'Ouest.

Brooks, M. R., Puckett, S. M., Hensher, D. A., \&Sammons, A. (2012). Understanding mode choice decisions: Astudy of Australian freight shippers. Maritime Economics and Logistics, 14, 274-299.

Cour des Comptes. (2006).Rapport public thématique sur les ports français face aux mutations maritimes: I'urgence de l'action. Paris:Cour des Comptes.

Dablanc, L. (2011).City distribution, a key element of the urban economy: Guidelines for practitioners. In C.Macharis\& S.Melo (Eds.), City distribution and urban freight transport: Multiples perspectives(pp. 13-36). Northampton, MA: Edward Elgar Publishing.

Debah, F. (2010).Thematic research summary: Waterborne transport. European Commission, DG Energy and Transport, Transport Research Knowledge Centre.

Delaître, L., \&de Barbeyrac, C. (2012). Improving an urban distribution centre: The French case of SamadaMonoprix.Procedia-Social and Behavioral Sciences, 39, 753-769.

De Langen, P. W., van der Horst, M. R., \&Koning,R. (2006).Cooperation and coordination in container barge transport.In J.Puig,R. MarcetiBarbé,\& V. G.Carcellé (Eds.),Maritime transport(Vol. 3 ; pp. 91- 
107). Barcelona: Technical University of Catalonia. Dept. of Nautical Science and Engineering;MuseuMaritim.

Ducret, R., \&Roset, A. (2014).Developing a territorial diagnosis and decision-making tool for urban goods distribution. Paper presented at the 8th Bi-Annual Conference on the E-commerce, Digital Economy and Delivery Services, Toulouse, April 2-4.

Eccles, R. (1981).Thequasifirm in the construction industry.Journal of Economic Behavior and Organization,2, 335-357.

EICB/BVB. (2009).Le fluvial, un mode de transport à forte valeur ajoutée:L'avenir du transport de marchandises et de la navigation fluviale en Europe 2010-2011. Rotterdam: Bureau VorlichtenBinnevaart with the Expertise enInnovatie Centrum Binnenvaart.

Fabbe-Costes, N., \&Roussat, C. (2011).Supply chain integration: Views from a logistics service provider. Supply Chain Forum,12(2), 20-30.

Fernandez, A., Arrunada, B., \&Gonzales-Diaz, M. (1998). Contractual and regulatory explanations of quasi-integration in the trucking industry.Economics and Business Working Paper Series, 292.UniversitatPompeuFabra.

Fischer, J., Monadier, P., \&Allais, V. (2003). Amélioration des conditions d'accès et de trafics fluviaux dans les ports et zones maritimes. Rapport $n^{\circ}$ 2003-0004-01.Paris: Conseil Général des Ponts et Chaussées.

Fischman, M.,\&Lendjel, E. (2011).Efficience du marché et contrats types: une analyse transactionnelle du contrat type d'affrètement au voyage dans le transport fluvial de fret.Les Cahiers Scientifiques du Transport,60,7-38.

Fischman, M., \&Lendjel, E. (2012).Changements institutionnels et efficience de l'affrètement au voyage dans le transport fluvial de marchandises. Recherche Transports et Sécurité, 28(3), 1-20.

Franc,P., \&Van der Horst,M. R. (2010). Understanding hinterland service integration by shipping lines and terminal operators: Atheoretical and empirical analysis.Journal of Transport Geography, 18, 557-566.

Frémont, A. (2012).Quel rôle pour le fleuve dans le grand paris des marchandises? Belin/L'EspaceGéographique,41(3), 236-251.

Frémont, A., Franc, P., \&Slack,B. (2009).Inland barge services and container transport: The case of the ports of Le Havre and Marseille in the European context.Cybergeo: EuropeanJournal of Geography, 437, 1-20.

Galbrun, X., \&Le Du, E. (2007).100 ans d'Union au service des ports français: 1907-2007. Paris: UNIM.

Gonzalez-Feliu, J., Semet, F., \&Routhier, J.L. (Eds.). (2014). Sustainable urban logistics: Concepts, methods and information systems. Heidelberg:Springer.

Gort, R. (2009).Design of an autonomous loading \& unloading inland barge: A concept for container transport on the Albert Canal. Master's thesis no. SDPO.09.021.M. Antwerpen:Delft University of Technology,SteunpuntGoederenstromen.

Greenport. (2013).The role of inland ports in urban logistics: Back to basics. Retrieved from http://www.greenport.com/news101/products-and-services/the-role-of-inland-ports-in-urbanlogistics-back-to-basics 
Guilbault, M. (dir.). (2008).Enquête ECHO «Envois-CHargeurs-Opérateurs de Transport»: résultats de référence, 56. Arcueil: Synthèse INRETS.

Henscher, D. A., \&Puckett, S. M. (2005).Refocusing the modelling of freight distribution: Development of an economic-based framework to evaluate supply chain behaviour in response to congestion charging.Transportation, 35, 573-602.

IAU. (2008).La place de l'île-de-France dans l'Hinterland du Havre: le maillon fluvial. Paris: Institut d'Aménagement et d'Urbanisme en lle de France.

Joskow, P. (1987). Contract duration and relationship-specific investments: Empirical evidence from coal markets. The American Economic Review,77(1), 168-185.

Klein, B. (1988).Vertical integration as organizational ownership: The Fisher Body-General Motors relationship revisited.Journal of Law, Economics and Organization,4(1), 199-213.

Kreutzberger, E. (2003).Impact of innovative technical concepts for load unit exchange on the design of intermodal freight networks.Transportation Research Record, 1820, 03-2200.

Lendjel, E. (2013).Pre- and end-haulage of containers in shipping chains: The neglected role of transaction costs in shippers' modal choices. Proceedings of thelnternational Association of Maritime Economists (IAME) 2013 Conference, Marseille, July3-5.

Macharis, C., \&Melo, S (Eds.). (2011).City distribution and urban freight transport: Multiples perspectives. Northampton, MA: Edward Elgar Publishing.

Monteverde, K., \&Teece, D. J. (1982).Appropriable rents and quasi-vertical integration.Journal of Law and Economics, 15(2), 321-328.

Morana, J., Gonzalez-Feliu, J., \&Semet, F. (2014).Urban consolidation and logistics pooling. In J. Gonzalez-Feliu, F.Semet, \& J. L. Routhier (Eds.), Sustainable urban logistics: Concepts, methods and information systems(pp. 187-210). Heidelberg:Springer.

Nemoto, T., Browne, M., Visser, J., \&Castro, J. (2006).Intermodal transport and city logistics. In E. Taniguchi\& R. G. Thompson (Eds.), Recent advances in city logistics(pp. 15-30).Amsterdam: Elsevier.

Niérat, P. (2014).La production fluviale sur le bassin Rhône-Saône.In M. Bernadet\& A. Frémont (Eds.), Fleuves et territoires(pp. 215-228). Mâcon: Institut de recherche du Val de Saône-Maconnais.

Notteboom, T. (2006).The time factor in liner shipping services.Maritime Economics\&Logistics,8,1939.

Paffoni, E. (2013). Renouveau du fluvial et dynamiques métropolitaines: le cas des ports fluviaux franciliens (1980-2010). PhD dissertation, IFSTTAR/Université Paris Est.

Panayides, P. M. (2002). Economicorganization of intermodal transport.Transport Reviews, 22(4), 401-414.

Raimbault, N. (2014). Ports de Paris: un pilote du développement logistique de la métropole parisienne ?In M. Bernadet\& A. Frémont (Eds.), Fleuves et territoires(pp. 115-127). Mâcon: Institut de recherche du Val de Saône-Maconnais.

Raynard, C. (2012). Pour un renouveau de la logistique urbaine. Note d'analysedu Centre d'Analyse Stratégique, 274.Retrieved fromhttp://www.strategie.gouv.fr/system/files/2012-04-02 logistiqueurbaine-na274.pdf 
Roy, J., Nollet, J.,\&Beaulieu, M. (2006). Reverse logistics networks and governance structures. Supply Chain Forum, 2(6), 58-67.

Ruester S. (2010). Recent developments in transaction cost economics. Resource Markets Working Paper,18. Retrieved fromhttp://www.sophia-ruester.de/files/paper TCE.pdf

Saeed, N. (2013).Cooperation among freight forwarders: Mode choice and intermodal freight transport. Research in Transportation Economics, 42, 77-86.

Steenken, D., Voss, S., \&Stahlbock, R. (2004).Container terminal operation and operations research: A classification and literature review.OR Spectrum,26,3-49.

TL \& Associés. (2006).Etude sur le niveau de consommation de carburant des unités fluviales françaises: efficacités énergétiques et émissions unitaires de $\mathrm{CO} 2$ du transport fluvial de marchandises. Final report $n^{\circ}$ 0303002.Angers: Agence De l'Environnement et de la Maîtrise de I’Energie (ADEME).

Van der Horst, M. R.,\&De Langen, P. W. (2008).Coordination in hinterland transport chains: A major challenge for the seaport community.Maritime Economics \& Logistics,10,108-129.

Van Hassel, E., \&Vanelslander, T. (2011).Developing a small barge convoy system to reactivate the use of inland waterway network.Final Report.Antwerp: Department of Transport and Regional Economics, University of Antwerp.

VNF. (2009). Guide du conteneur fluvial. Paris: Voies Navigables de France. Retrieved from www.vnf.fr

Wiegmans, B. W. (2005).Evaluation of potentially successful barge innovations.Transport Reviews, 23(5), 573-589.

Wiegmans, B. W., \&Konings, R. (2007).Strategies and innovations to improve the performance of barge transport. European Journal of Transport and Infrastructure Research, 7(2), 145-162.

Williamson, O. (1996).The mechanisms of governance. Oxford: Oxford University Press.

Williamson, O. (2010).Transaction cost economics: The natural progression.The American Economic Review,100(3), 673-690.

Yvrande-Billon, A., \&Ménard, C. (2005). Institutional constraints and organizational changes: The case of the British rail reform. Journal of Economic Behavior\& Organization, 56, 675-699.

Zhao, W., \&Goodchild, A. V. (2010).The impact of truck arrival information on container terminal rehandling.Transportation Research Part E, 46, 327-343.

Zurbach, V. (2005).Transports de conteneurs sur le Rhin: quelles logiques de fonctionnement? Unpublishedmaster's dissertation.Paris : XII-ENPC-INRETS. 